\title{
The effect of density on the cultivation of the native mangrove oyster Crassostrea tulipa (Lamarck, 1819)
}

\author{
Lincon José Brunetto ${ }^{1}$, Carlos Henrique Araújo de Miranda Gomes ${ }^{1}$, Cassio de Oliveira Ramos ${ }^{1}$ \\ Francisco Carlos da Silva ${ }^{1}$, João Paulo Ramos Ferreira ${ }^{1}$ \\ Graziela Cleusa Vieira ${ }^{1} \&$ Claudio Manoel Rodrigues De Melo ${ }^{1}$ \\ ${ }^{1}$ Laboratory of Marine Mollusks, Department of Aquaculture, Federal University of Santa Catarina \\ Florianopolis, Brazil \\ Corresponding author: Claudio Manoel Rodrigues De Melo (claudio.melo@ufsc.br)
}

\begin{abstract}
In Brazil, the cultivation of Crassostrea tulipa (= C. gasar) is gaining in importance. However, little is known about the best conditions for farming. Therefore, this study aimed to evaluate the effect of oyster density $\left(50,100,200\right.$, and $400 \mathrm{~mL}$ of seeds $/ 0.15 \mathrm{~m}^{2} ; 100,200,300$, and $400 \mathrm{ind} / 0.10 \mathrm{~m}^{2}$ (basket area) and 30 , 60,120 , and $180 \mathrm{ind} / 0.13 \mathrm{~m}^{2}$ (lantern floor area) in nursey, juvenile and adult phase, respectively) on the growth and survival of $C$. tulipa in farm cultivation. In the nursery phase, the $50 \mathrm{~mL}$ density resulted in smaller oyster size, as expressed in height and height/length $(\mathrm{H} / \mathrm{L})$ ratio $(1.31 \pm 0.03 \mathrm{~mm})$, compared to other densities, while the length and width was equal among densities. The animals' individual average weight and $\mathrm{H} / \mathrm{L}$ ratio were negatively influenced by a density of $100 \mathrm{ind} / 0.10 \mathrm{~m}^{2}$ or bigger. However, animals grown at the density of 200 ind $/ 0.10 \mathrm{~m}^{2}$ did not differ statistically in length or width from those grown with $100 \mathrm{ind} / 0.10 \mathrm{~m}^{2}$. A high survival rate ( $\geq 98 \%)$ was found in the nursery and juvenile phases.
\end{abstract}

Keywords: Crassostrea tulipa; oyster culture; density; commercial size; hanging culture

\section{INTRODUCTION}

Crassostrea tulipa $(=$ C. gasar $)($ Lamarck, 1819$)$ is a tropical mangrove oyster first described to estuarine zones from Senegal to Angola (Ranson, 1948; Sandisson, 1966), with distribution, now verified by molecular markers, from Venezuela to Brazil (Lapègue et al., 2002; Pie et al., 2006; Carpenter \& De Angelis, 2016), being conspecific with $C$. brasiliana (Lamarck, 1819), its synonym (Lazoski et al., 2011). In South America, the species predominates in the eastern Brazil ecoregion (Carranza et al., 2009). It is commonly associated with brackish water bordering the coast where mangroves grow, living on fallen branches, tree trunks, and mangrove roots (Caryé, 1981), but in Brazil, the species stands out for its preference for the infralittoral habitat, i.e., rocky coastal regions (Christo \& Absher, 2006).

The species is historically associated with traditional littoral people of Africa who view this oyster as a source of protein, as well as a source of income, by the direct exploitation of its natural stock or by the cultivation of mangrove roots bearing the oysters (Gruvel, 1913; Nicklès, 1950; Ajana, 1980; Cham, 1992), and these practices continue in some localities (Ansa \& Bashir, 2007; Adite et al., 2013; Crow \& Carney, 2013).

In Brazil, C. tulipa has fair economic importance, and it is cultivated in tropical coastal areas where the cultivation of $C$. gigas (Thunberg, 1793) is otherwise impractical (Gomes et al., 2014). The preference for farming this mangrove oyster species is based on its faster growth and larger size in comparison to $C$. rhizophorae (Guilding, 1828) (Legat et al., 2017a), a sympatric species occurring from the US Florida coast to Uruguay (Rios, 2009). Indeed, the exploitation of these oysters in their natural stocks is one of the most recognizable traditional activities along the Brazilian coast (Wakamatsu, 1973), and it serves as a source of income in many communities (Ramos et al., 2013). However, in some locations, the unsustainable harvesting of mangrove oysters compromises their natural stocks, especially in the littoral zone of São Paulo

Corresponding editor: Cesar Lodeiros 
(Mendonça \& Machado, 2010) and Paraná (Westphal \& Ostrenski, 2016).

C. tulipa is known for its inherent palatability (Antunes \& Itô, 1968), it has potential as a species for farming (Angell, 1986). Studies proposing the development of such activity have been performed in the context of economic, health, and environmental issues arising from the new market demand (Wakamatsu, 1973; Kamara, 1982; Afinowi, 1984; Pereira \& Soares, 1996).

The farming of mangrove oyster species, however, still relies, almost exclusively, on the extraction of seeds from the wild by artificial collectors (Nalesso et al., 2008; Gardunho et al., 2012; Christo et al., 2016; Diadhiou \& Ndour, 2017; Oliveira et al., 2018; Funo, 2019; Tureck et al., 2020). The implications of utilizing such a method involve the difficulty of correct species identification, including the high polymorphism of Crassostrea oysters in areas of sympatric occurrence (Reece et al., 2008), small capacity for seeds settlement by structure (ranging from $\sim 5.000$ to 20.000 seeds, according to Galvão et al., 2009) and the likelihood of different seed ages attaching to the same structure. Moreover, collecting oyster spat may prove inconsistent as the reproductive cycle of $C$. tulipa is greatly influenced by low salinity (Zabi \& Le Loeuff, 1992; Paixão et al., 2013; Gomes et al., 2014). Only in recent years, as our knowledge of reproductive biology of $C$. tulipa improved (Ramos et al., 2013, 2014; Gomes et al., 2014), has the establishment of seed supplies for farming through induced spawning and broodstock selection become available.

Studies reporting on the cultivation of $C$. tulipa have been conducted along the Brazilian coastline to evaluate oyster growth in estuarine zones of Pará (Funo et al., 2015; Oliveira et al., 2018), Maranhão (Legat et al., 2017b), and São Paulo (Pereira et al., 2001; Galvão et al., 2009) to promote oyster cultivation. However, oyster farming based on wild seeds or adults occurs diffusely from Pará $\left(0^{\circ} 38^{\prime} \mathrm{S}, 47^{\circ} 50^{\prime} \mathrm{W}\right)$ to Paraná (2552'S, 4834'W) coasts (Legat et al., 2008). Cultivation of $C$. tulipa thorough the central to northern littoral zone of Brazil is conducted in estuarine ecosystems, marine areas usually attributed to either extractive fishing (MPA, 2011) or other unrelated economic activities. The use of artisanal rack structure in the intertidal zone for farming is also a common practice of farmers in this region, implying lower production costs (Angell, 1986) since it is conducted by traditional family communities (Nascimento, 1990).

The northern and southern bays of Santa Catarina Island (from $27^{\circ} 25^{\prime} \mathrm{S}, 48^{\circ} 31^{\prime} \mathrm{W}$ to $27^{\circ} 49^{\prime} \mathrm{S}, 48^{\circ} 34^{\prime} \mathrm{W}$ ) are responsible for $97 \%$ of the Brazilian oyster culture coming from hatchery-produced seeds (EPAGRI,
2018; IBGE, 2019). However, only a small percentage (approximately 10\%) belongs to C. tulipa production. Also, C. tulipa cultivation, in this particular area, follows the same farming steps proposed for the cultivation of $C$. gigas: floating wooden boxes for nursery, oyster basket for juveniles, and oyster lantern for final grow-out (Mizuta et al., 2012).

To enhance oyster production, knowledge of optimal culture density is an essential factor (Taylor et al., 1997), and some studies of oyster species cultivated in Brazil have reported on this metric. In Brazil, stocking density evaluation has already been conducted for C. rhizophorae (Maccacchero et al., 2005; CardosoJunior et al., 2012), C. gigas (Ferreira \& Ferreira, 2014; Roncarati et al., 2017) as well as C. tulipa with individuals acquired from the wild (Pereira et al., 2001; Galvão et al., 2009). However, an evaluation of stocking density in the marine environment in the bays of Santa Catarina has never been performed, especially covering every phase of cultivation.

Therefore, this study aimed to evaluate the effect of oyster density on the growth and survival of $C$. tulipa cultivated at different densities at nursery, juvenile and adult phases to provide technical support for the species' production in Brazil.

\section{MATERIALS AND METHODS}

The present study was carried out at Fazenda Marinha Atlântico Sul located in Ribeirão da Ilha, Florianópolis/SC (2744’31.29”S; 48³3’29.66”W), a representative site for Crassostrea tulipa cultivation, since the vast majority of farms in Brazil are located around of this site.

\section{Environmental parameters}

During the experimental period, the water temperature was recorded hourly using the Data Logger StowAway ${ }^{\circledR}$ Tidbit $^{\circledR}$ sensor. Salinity was observed four times a week through a Biobrix ${ }^{\circledR}$ refractometer (Model 211). Concentrations of total particulate matter (TPM), particulate inorganic matter (PIM), and particulate organic matter (POM) were determined weekly throughout the experimental period by adopting the methodology described by Strickland \& Parsons (1972).

Water samples were collected weekly at a depth of $45 \mathrm{~cm}$. These samples were collected in $1 \mathrm{~L}$ amber bottles and stored at $4{ }^{\circ} \mathrm{C}$ until laboratory analyses were performed. Then, $250 \mathrm{~mL}$ of water samples were filtered on $47 \mathrm{~mm}$ diameter Macherey-Nagel GF-3 filters, previously washed with distilled water, calcined, and weighed. At the end of each filtration, the sample filters were rinsed with ammonium formate $(0.5 \mathrm{~N})$ to 
remove the salts. TPM values were obtained after drying the filters containing samples in an oven at $60^{\circ} \mathrm{C}$ for $24 \mathrm{~h}$. PIM values were obtained by calcining the TPM samples at $450^{\circ} \mathrm{C}$ for $2 \mathrm{~h}$, and POM values were determined by the difference between TPM and PIM $\left(\mathrm{mg} \mathrm{L}^{-1}\right)$. The index was obtained by the PIM/POM ratio.

\section{Spawning, larviculture, and spat nursery}

Spawning was performed in December of 2015, using oysters from the breeding stock of $C$. tulipa specimens from the Laboratório de Moluscos Marinhos of the Universidade Federal de Santa Catarina (LMM/UFSC). Spawning, larviculture, and spat nursery were performed as described by Silveira et al. (2011). Cultivation steps in grow-out farms followed Mizuta et al. (2012), in which, herein, the nursery phase consisted of oysters ranging from 1.5 to $20 \mathrm{~mm}$ in size, while, in the juvenile phase, oysters ranged from $<20$ to $50 \mathrm{~mm}$ in size.

\section{Nursery phase}

This phase of the experiment occurred from July to November 2016. Seven hundred seventeen thousand seeds retained in a $1.5 \mathrm{~mm}$ size mesh (mean height 2.50 $\pm 0.30 \mathrm{~mm}$ ) were used to experiment. The experimental design was performed in a completely randomized block with four treatments (density of 50,100,200, and $400 \mathrm{~mL}$ seeds $/ 0.15 \mathrm{~m}^{2}$, respectively $11,950,23,900$, 47,800 and 95,600 seeds $/ 0.15 \mathrm{~m}^{2}$ ) in quadruplicate. Considered the best structure for oyster growth performance at this phase (Ferreira \& Ferreira, 2014), the seeds were kept in floating wooden boxes measuring $92 \times 79.5 \times 20 \mathrm{~cm}$ (length $\times$ width $\times$ height $)$ and subdivided into four compartments with an area of 0.15 $\mathrm{m}^{2} /$ compartment and volume of $0.03 \mathrm{~m}^{3} /$ compartment and covered with a mesh size of $0.710 \mathrm{~mm}$. Each compartment formed an experimental unit (EU). The boxes were washed weekly with a pressurized freshwater jet.

The first sieving of seeds, by size, occurred at 42 days of cultivation, using a set of sieves with 1.5 and 3 $\mathrm{mm}$ mesh. The seeds were again stocked at the same densities $\left(50,100,200\right.$, and $400 \mathrm{~mL}$ seeds $\left./ 0.15 \mathrm{~m}^{2}\right)$ after sieving; the box was covered with $1 \mathrm{~mm}$ mesh. At 72 days of cultivation, the seeds were sieved again using a set of sieves with 3 and $6 \mathrm{~mm}$ mesh; the seeds were populated in boxes covered with $4 \mathrm{~mm}$ mesh, keeping the initial densities (50, 200, 200 and 400 seeds $\mathrm{mL} / \mathrm{EU})$. Final sieving, using sieves with 6 and $16 \mathrm{~mm}$ mesh, was carried out at 114 days of culture.

Estimates of survival (number of live seeds / initial number of seeds) and shell dimensions ( $\mathrm{n}=50 / \mathrm{EU} /$ size class) were carried out with each sieving. The measurements taken were shell height $(\mathrm{mm})$ and shell length $(\mathrm{mm})$, using a Starrett ${ }^{\circledR}$ digital caliper $(0.1 \mathrm{~mm})$.

\section{Juvenile phase}

From the total number of seeds obtained in the nursery phase, 16,000 seeds were taken randomly and placed in $0.10 \mathrm{~m}^{2}$ baskets; four attached trays formed a set. The experimental design at this stage was completely randomized. Four culture densities of 100, 200, 300, and $400 \mathrm{ind} / 0.10 \mathrm{~m}^{2}$ (basket) were evaluated with 16 replicates/treatment.

The juvenile phase was concluded after 48 days of cultivation, and the fouling was removed using a freshwater pressurized jet, and oysters were individually scraped for cleaning. The survival rate was calculated, and the animals' total live weight from each experimental unit was measured using the Shimadzu ${ }^{\circledR}$ precision digital scale (Model UX4200H - $0.0001 \mathrm{~g}$ ). Biometry was performed with the aid of a Starrett ${ }^{\circledR}$ digital caliper $(0.1 \mathrm{~mm})$, using measurements of shell height $(\mathrm{mm})$, shell length $(\mathrm{mm})$, and shell width $(\mathrm{mm})$.

\section{Grow-out phase}

The grow-out phase was carried out from January to October 2017. A total of 6,240 oysters from the juvenile phase were used. The animals were distributed in lanterns with a $24 \mathrm{~mm}$ mesh opening, containing five floors with an area of $0.13 \mathrm{~m}^{2}$. Measurements of total live weight $(\mathrm{g})$ of each experimental unit were accomplished using the Shimadzu ${ }^{\circledR}$ precision digital scale.

The experimental design was completely randomized, and the densities tested were $30,60,120$, and $180 \mathrm{ind} / 0.13 \mathrm{~m}^{2}$ (lantern floor) with 16 replications/ treatment. Management of the experimental units was carried out monthly, consisting of washing using a high-pressure freshwater jet and an individual scraping of oysters with a cleaver to remove fouling before the evaluations.

At the tenth month of culture, survival (\%), shell height, length, and width $(\mathrm{mm})(\mathrm{n}=30 \mathrm{ind} /$ replicate $)$ were carried out. The measurements were taken according to Galtsoff (1964), using an analog caliper. The oysters' weight was taken using the Shimadzu ${ }^{\circledR}$ digital precision scale. All oysters in different size classes ( $<60, \geq 60$ to $<80$, and $\geq 80 \mathrm{~mm}$ ) were evaluated using an analog caliper. The measurements were taken according to Galtsoff (1964).

\section{Statistical analysis}

Survival and growth data (height, length, height/length ratio $(\mathrm{H} / \mathrm{L})$, width, individual average weight) were submitted to the normality (Shapiro-Wilk), and homosce- 
dasticity of variances (Levene) tests. Subsequently, ANOVA was applied. When a difference between the averages of treatments was found, Tukey's test was applied at a significance level of 5\%. All analyses were performed using the SAS ${ }^{\circledR}$ program (SAS, 2003).

\section{RESULTS}

\section{Environmental parameters}

The lowest salinity mean was observed at the end of January $2017(26 \pm 1.41)$ and the highest was detected in September 2017 (35.80 \pm 0.45$)$, with a mean of 32.85 \pm 2.15 . The lowest average temperature was recorded in August $2016\left(16.82 \pm 0.71^{\circ} \mathrm{C}\right)$, and the highest in February $2017\left(28.67 \pm 0.64^{\circ} \mathrm{C}\right)$; the overall mean was $21.81 \pm 3.13^{\circ} \mathrm{C}$ (Fig. 1).

Throughout the experimental period, TPM, PIM, and POM values showed their lowest and highest mean values, respectively, in June 2017 and November 2016. TPM's average values ranged from $25.98 \pm 6.34$ to $84.76 \pm 6.65 \mathrm{mg} \mathrm{L}^{-1}$ with an overall mean of $54.67 \pm$ $14.43 \mathrm{mg} \mathrm{L}^{-1}$. For PIM, the averages varied from 19.55 \pm 4.13 to $67.35 \pm 5.33 \mathrm{mg} \mathrm{L}^{-1}$ with a general mean of $39.66 \pm 9.83 \mathrm{mg} \mathrm{L}^{-1}$, while POM averages varied (Fig. 2) from $6.43 \pm 2.66$ to $17.41 \pm 5.33 \mathrm{mg} \mathrm{L}^{-1}$ with an overall mean of $10.42 \pm 2.93 \mathrm{mg} \mathrm{L}^{-1}$. The average values of the PIM/POM ratio showed an overall mean of $4.61 \pm 1.73$, while the minimum and maximum values encountered for this parameter ranged from 1.31 to 10.64 .

\section{Nursery phase}

The first evaluation carried out at 42 days of cultivation demonstrated significant differences among the densities for height in the seeds retained in the $3 \mathrm{~mm}$ mesh (Fig. 3). Seeds grown at densities of $400 \mathrm{~mL} / 0.15$ $\mathrm{m}^{2}$ had the highest mean height of $6.15 \pm 0.14 \mathrm{~mm}$, while those grown at a density of $50 \mathrm{~mL} / 0.15 \mathrm{~m}^{2}$ presented the lowest mean of $4.99 \pm 0.18 \mathrm{~mm}$, with no differences for mean length. $\mathrm{H} / \mathrm{L}$ values were higher in seeds retained at $3 \mathrm{~mm}$ mesh grown at a density of 400 $\mathrm{mL} / 0.15 \mathrm{~m}^{2}(1.22 \pm 0.03)$, reflecting their high height value (Fig. 3). Seeds retained at $1.5 \mathrm{~mm}$ mesh exhibited similar growth $(P>0.05)$ for all densities tested (Fig. $3)$.

In the second evaluation, at 72 days of cultivation, seeds surpassed the $3 \mathrm{~mm}$ size category since they were all retained at the $6 \mathrm{~mm}$ mesh size category. The higher values of height come from seeds grown at a density of $400 \mathrm{~mL} / 0.15 \mathrm{~m}^{2}(13.92 \pm 0.63 \mathrm{~mm})$ and $200 \mathrm{~mL} / 0.15$ $\mathrm{m}^{2}(12.78 \pm 0.23 \mathrm{~mm})$, showing a significant difference between them and from each other. Likewise, the average length and H/L ratio of seeds retained at the 6 $\mathrm{mm}$ mesh size after sifting was higher at a density of $400 \mathrm{~mL} / 0.15 \mathrm{~m}^{2}(11.56 \pm 0.20$ and $1.20 \pm 0.04$, respectively). It should be noted that the density of 200 $\mathrm{mL} / 0.15 \mathrm{~m}^{2}$ treatment did not differ from seeds grown at densities of $50 \mathrm{~mL} / 0.15 \mathrm{~m}^{2}$ and $100 \mathrm{~mL} / 0.15 \mathrm{~m}^{2} \quad(P$ $>0.05$ ) (Fig. 3).

In the third and final evaluation carried out at 114 days of cultivation, the seeds retained in the $6 \mathrm{~mm}$ mesh did not exhibit significant differences in any other attribute besides length, in which the density of 400 $\mathrm{mL} / 0.15 \mathrm{~m}^{2}$ showed the lowest values differing from $100 \mathrm{~mL} / 0.15 \mathrm{~m}^{2}$ (Fig. 4). For the seeds retained in the $16 \mathrm{~mm}$ mesh, differences were only noted in height, and the $\mathrm{H} / \mathrm{L}$ ratio between seeds cultivated at $50 \mathrm{~mL} / 0.15$ $\mathrm{m}^{2}$, in that seeds of this treatment was more rounded than the seeds cultivated at the lowest density (Fig. 4).

\section{Juvenile phase}

The cultivated oyster growth results at a different density per basket exhibited a particular pattern in which oysters appeared longer and wider with individual average weight most directly affected by decreasing density in cultivation (Fig. 5). More specifically, oysters cultivated at 100 ind $/ 0.10 \mathrm{~m}^{2}$ presented the highest values of individual average weight and a more rounded conformation, as corroborated by the lowest $\mathrm{H} / \mathrm{L}$ ratio values, in comparison to any other treatment. The survival rate of oysters cultivated at 400 ind $/ 0.10 \mathrm{~m}^{2}$ was higher, though all other density treatments' survival rate reached at least $98 \%$ (Fig. 5).

The growth of oysters in the juvenile phase occurred primarily in height and length. Height and length in late cultivated juvenile oysters (Fig. 5) ranged from $50.51 \pm$ 3.77 to $52.54 \pm 3.16 \mathrm{~mm}$ and $34.24 \pm 3.39$ to $39.38 \pm$ $2.66 \mathrm{~mm}$, respectively, while in seeds retained at 16 $\mathrm{mm}$ mesh (Fig. 4), values varied from $26.78 \pm 0.74$ to $28.69 \pm 0.74 \mathrm{~mm}$ in height and $20.15 \pm 0.67$ to $20.50 \pm$ $0.26 \mathrm{~mm}$ in length. For width, though, values were similar, as indicated by seeds retained at the $16 \mathrm{~mm}$ mesh (Fig. 4), varying from $9.68 \pm 1.84$ to $10.94 \pm 2.75$ $\mathrm{mm}$, while juvenile oysters (Fig. 5) varied from $9.34 \pm$ 0.87 to $10.38 \pm 0.92 \mathrm{~mm}$.

Differences were perceived at different densities of cultivation. As density increased, the length of oysters and individual average weight decreased. The lowest density of $100 \mathrm{ind} / 0.10 \mathrm{~m}^{2}$ showed $39.38 \pm 2.66 \mathrm{~mm}$ in length and an individual average weight of $12.78 \pm 1.45$ $\mathrm{g}$, while the highest density of $400 \mathrm{ind} / 0.10 \mathrm{~m}^{2}$ showed the lowest values for both parameters $(34.24 \pm 3.39 \mathrm{~mm}$ length and $8.56 \pm 1.56 \mathrm{~g}$, respectively) (Fig. 5). Higher density treatment $\left(400 \mathrm{ind} / 0.10 \mathrm{~m}^{2}\right)$ also showed a small $\mathrm{H} / \mathrm{L}$ ratio $(1.48 \pm 0.13)$ when compared with small density treatment $\left(100 \mathrm{ind} / 0.10 \mathrm{~m}^{2}\right.$ and $\mathrm{H} / \mathrm{L}$ 


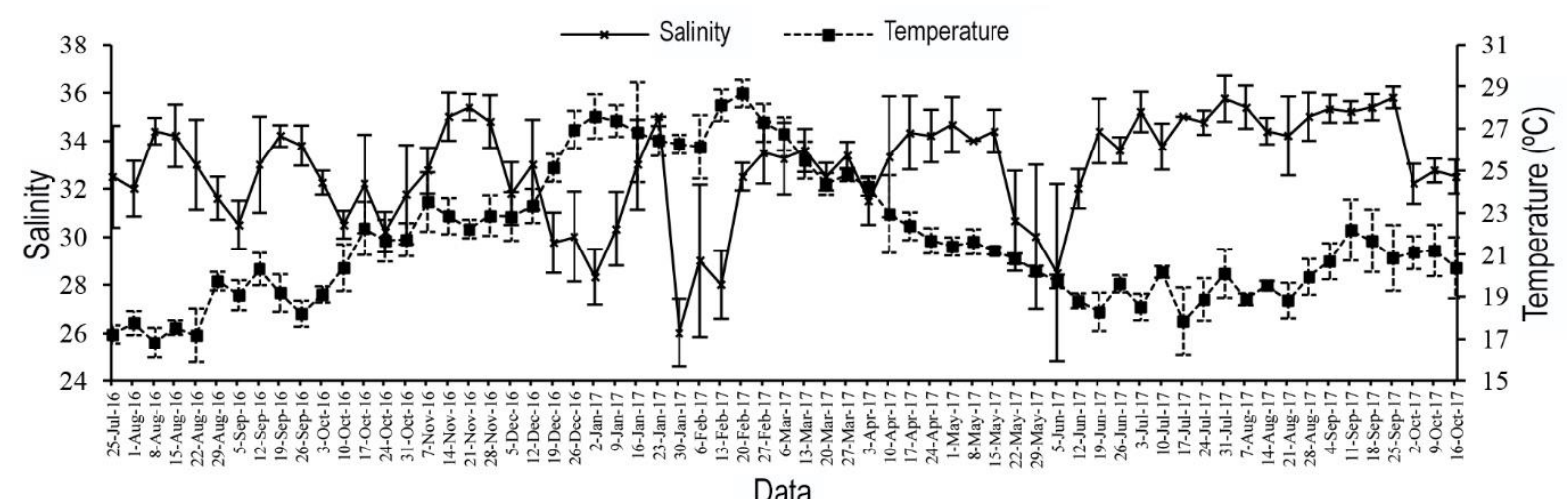

Figure 1. Salinity and temperature $\left({ }^{\circ} \mathrm{C}\right)$ of water during the experimental period. The bar represents the standard deviation.

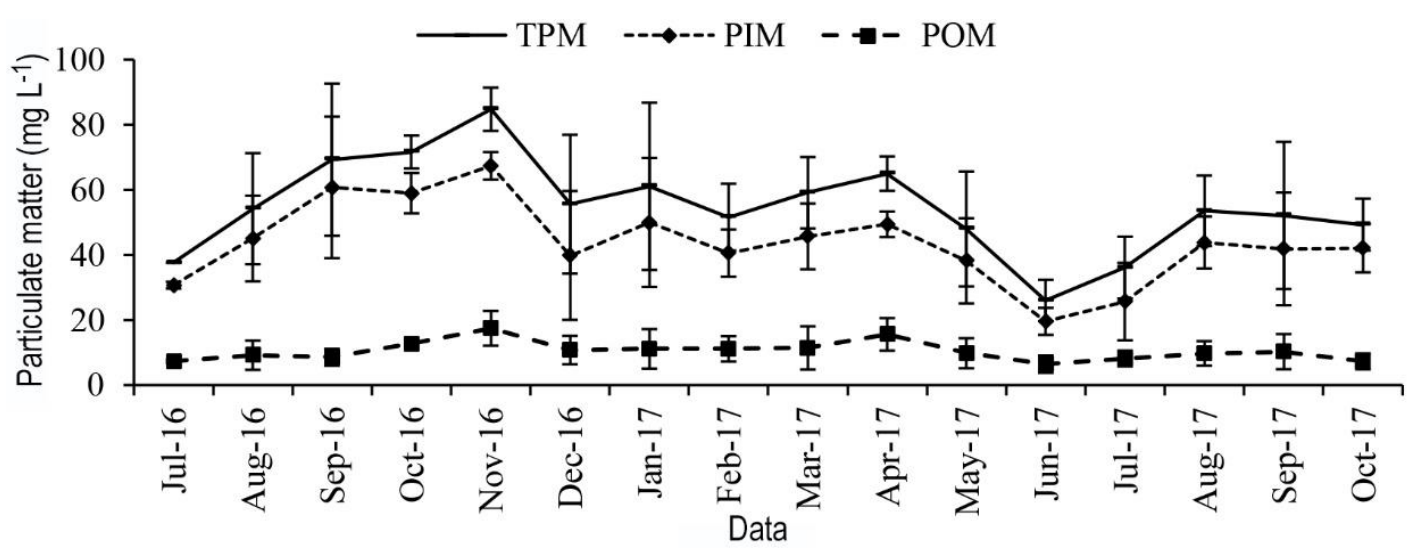

Figure 2. Total (TPM), inorganic (PIM), and organic (POM) particulate matter during the experimental period. The bar represents the standard deviation.

$1.31 \pm 0.07$ ), implicating narrower juveniles. The survival rate in this phase-maintained value greater than 98\% in all treatments; however, survival and density 100 was statistically higher.

\section{Final grow-out}

During the final phase of cultivation, in higher density, height and $\mathrm{H} / \mathrm{L}$ ratio of individuals exhibited higher values, while length showed lower values, except the 30 ind $/ 0.13 \mathrm{~m}^{2}$ treatment, which did not differ significantly from those of other treatments (Fig. 5). The cultivated oysters' width showed similar values among treatments, varying from $26.54 \pm 0.97$ to 28.40 $\pm 1.39 \mathrm{~mm}$, a significant growth compared to the previous cultivation phase, forming a cupped-shape shell.

Mean values of the individual average weight of oysters cultured at 30 and $60 \mathrm{ind} / 0.13 \mathrm{~m}^{2}(87.91 \pm 9.48$ and $87.70 \pm 9.95 \mathrm{~g}$, respectively) showed the lowest values when compared to oysters cultured at a density of $120(91.06 \pm 7.62 \mathrm{~g})$ and $180(90.32 \pm 6.17 \mathrm{~g})$ ind $/ 0.13 \mathrm{~m}^{2}$. Also, differences were noted between oysters grown at densities of 180 and 120 , and densities of both 30 and $60 \mathrm{ind} / 0.13 \mathrm{~m}^{2}$ (Fig. 5).

\section{Size class after ten months of cultivation}

The survival rate was $75.06 \pm 4.38 \%$ (Fig. 5), considering the performance growth of oysters at 120 ind $/ 0.13 \mathrm{~m}^{2}$, showing that $54.88 \pm 5.88$ individuals reached the height of $\geq 80 \mathrm{~mm}$, providing a total of $5.177 \pm 0.439 \mathrm{~kg}$ of oysters. As for the oysters, the height of which ranged from $\geq 60$ to $<80 \mathrm{~mm}, 25.38 \pm$ 2.06 individuals provided a total of $1.391 \pm 0.222 \mathrm{~kg}$ (Fig. 6).

Superior results were also found in the performance growth of oysters at a density of $180 \mathrm{ind} / 0.13 \mathrm{~m}^{2}$ in that these oysters had a survival rate of $76.53 \pm 7.28 \%$, among which $63.17 \pm 3.38$ individuals reached a height of $\geq 80 \mathrm{~mm}$, providing $5.813 \pm 0.169 \mathrm{~kg}$. Oysters with a height ranging from $\geq 60$ to $<80 \mathrm{~mm}$ at this density totaled $54.50 \pm 1.95$ individuals with a total weight of $2.977 \pm 0.230 \mathrm{~kg}$ of oysters suitable for commercialization (Fig. 6). Other density treatments showed lower results in both the number and weight of oysters (Fig. 6) and the lowest rates of survival (Fig. 5). 
$\square 50 \square 100 \square 200 \square 400$
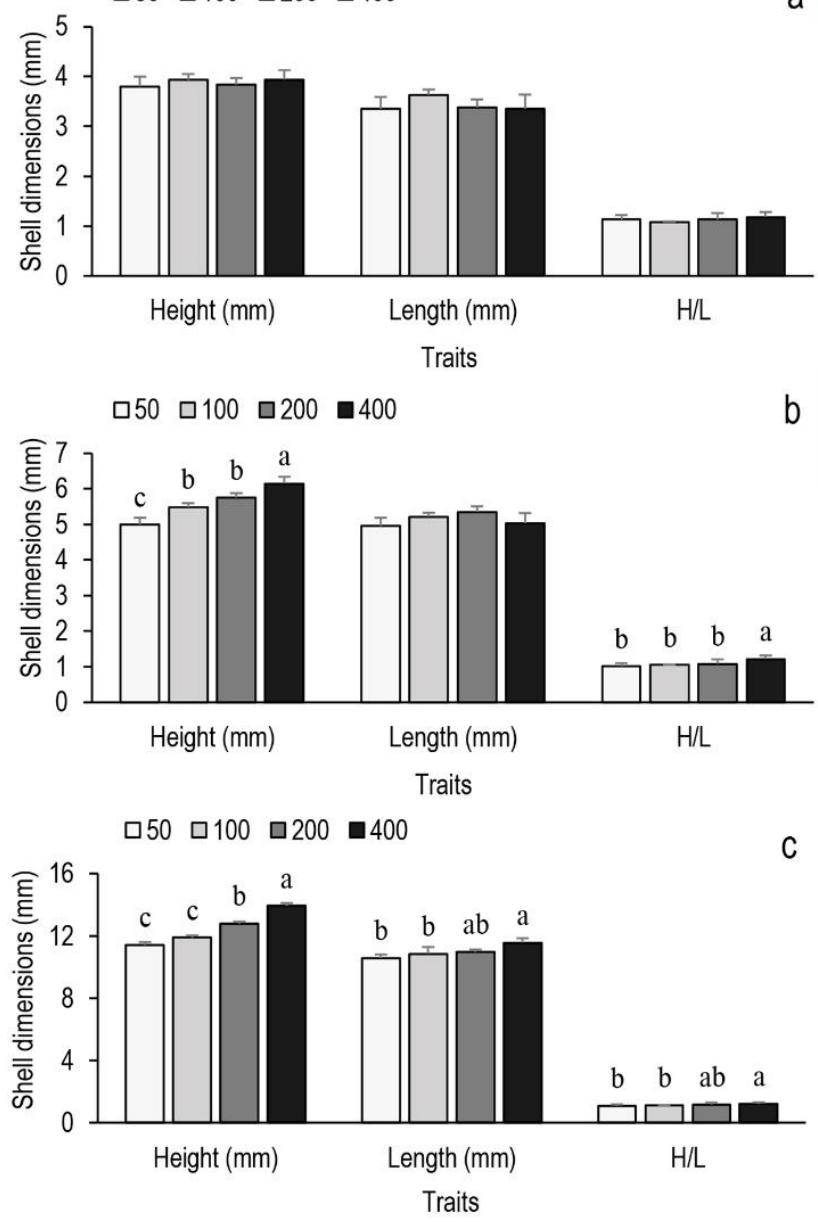

Figure 3. Mean \pm standard deviation of height $(\mathrm{mm})$, length $(\mathrm{mm})$, height/length ratio $(\mathrm{H} / \mathrm{L})$, and width $(\mathrm{mm})$ of Crassostrea tulipa oyster seeds after a), b) 42 and c) 72 days of nursery culture in the field in different density treatments. Figure shows seeds retained at a) $1.5 \mathrm{~mm}$ mesh, b) $3 \mathrm{~mm}$ mesh, c) $6 \mathrm{~mm}$ mesh. Density treatments are $50,100,200$, and $400 \mathrm{~mL}$ of oyster seeds $/ 0.15 \mathrm{~m}^{2}$. Least square means with different letters in the column were significantly different $(P<0.05)$ by Tukey's test.

\section{DISCUSSION}

For most density treatments throughout all farm phases, the cultivation of Crassostrea tulipa presented good performance. All four densities provide satisfactory results for nursery phase cultivation, even though some differences are significant among shell dimensions, as individuals reached suitable size for the juvenile phase of cultivation (at least $20 \mathrm{~mm}$ height). Most parameters evaluated in oyster growth maintained similar values for the juvenile phase except for width and individual average weight where treatments of 100 and 200 ind $/ 0.10 \mathrm{~m}^{2}$ exhibited the highest values. As for the grow-out phase, a density of $120 \mathrm{ind} / 0.13 \mathrm{~m}^{2}$ seems ideal $\square 50 \square 100 \quad \square 200 \quad \square 00$
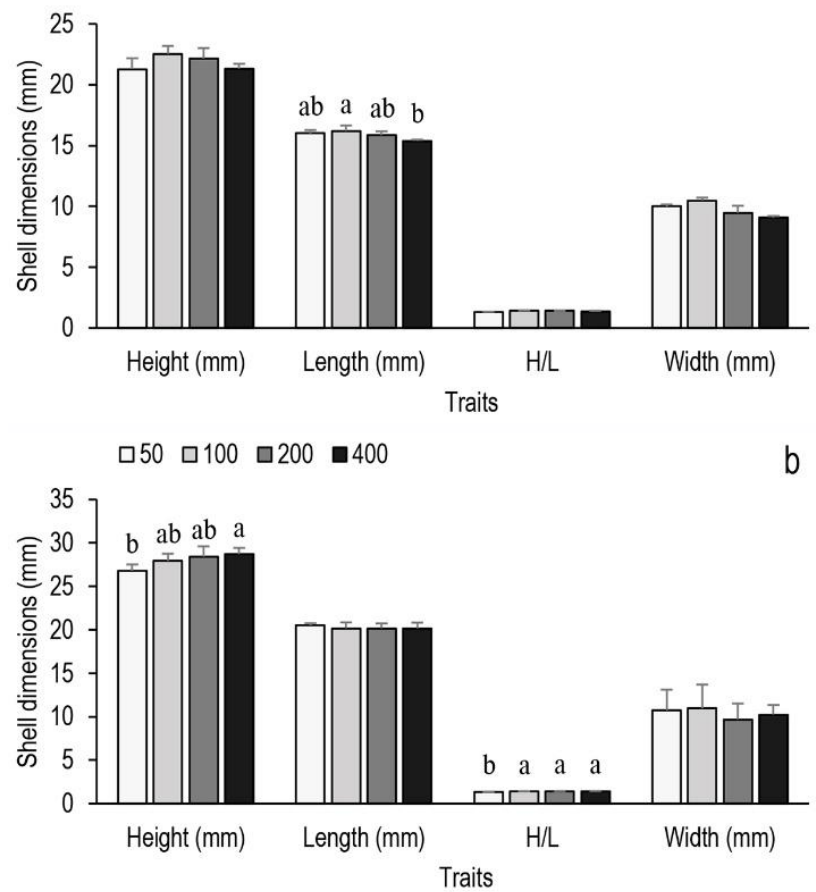

Figure 4. Mean \pm standard deviation of height $(\mathrm{mm})$, length $(\mathrm{mm})$, height/length ratio $(\mathrm{H} / \mathrm{L})$, and width $(\mathrm{mm})$ of Crassostrea tulipa oyster seeds after 114 days of nursery culture in the field in different density treatments. a) Shows seeds retained at $6 \mathrm{~mm}$ mesh, and b) shows seeds retained at $16 \mathrm{~mm}$ mesh. Density treatments are 50, 100, 200 , and $400 \mathrm{~mL}$ of oyster seeds $/ 0.15 \mathrm{~m}^{2}$. Least square means with different letters in the column were significantly different $(P<0.05)$ by Tukey's test.

for acquiring most commercial oysters with heavier individual average weight.

The attempt to cultivate $C$. tulipa in marine areas seems quite diffuse in the literature. Cayré (1981) reports that mangrove oysters placed in cages and cultivated in a marine environment presented initial mortality of $16 \%$, but the specimens' growth was higher, and the specimens acquired better palatability than those cultivated in the mangrove. Lopes et al. (2013) showed that $C$. tulipa seeds cultivated in Santa Catarina for a year exhibited a higher initial growth, until the $240^{\text {th }}$ day of cultivation, in the marine site compared to the estuarine site [marine oysters with a mean of $31.5 \pm 6.6$ height $\times 25.6 \pm 4.5$ length $\mathrm{mm}$ and estuarine oysters with $27.0 \pm 13.2$ height $\times 22.6 \pm 10.2$ length $\mathrm{mm}$. The same study also demonstrated that oysters in the estuarine site surpassed, in mean shell height and length, oysters cultivated in the marine site in the last four months of cultivation, with $75.86 \%$ of oysters reaching height values of at least $50 \mathrm{~mm}$, in comparison to $42.92 \%$ of oysters in the marine site (Lopes 

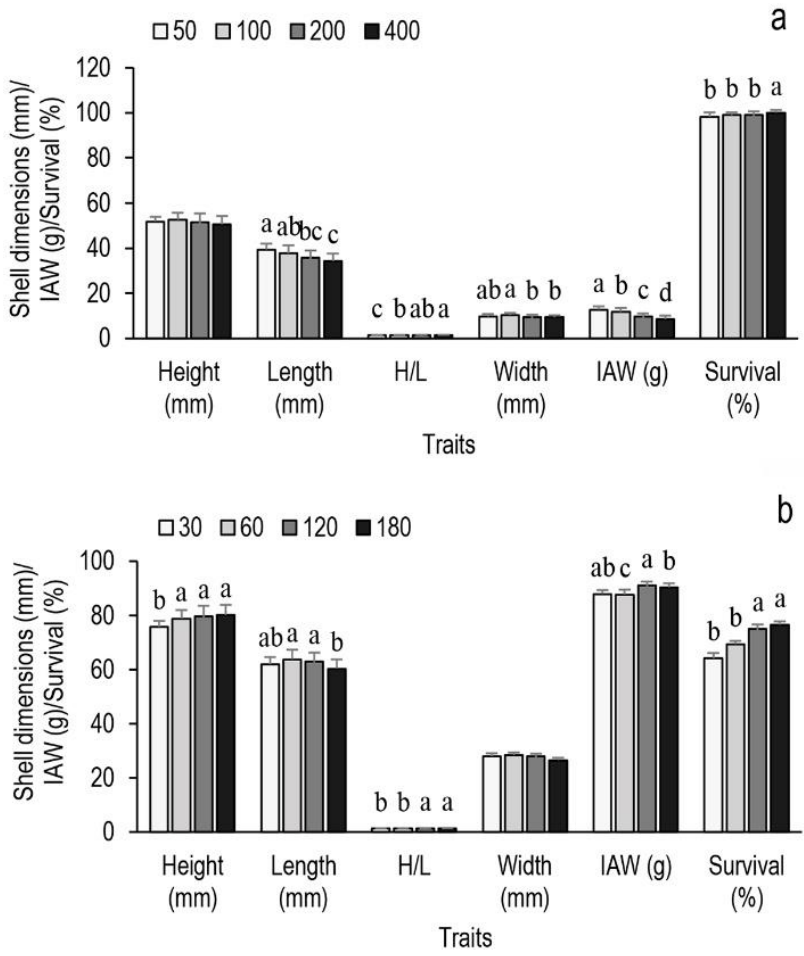

Figure 5. Mean \pm standard deviation of height $(\mathrm{mm})$, length $(\mathrm{mm})$, height/length ratio $(\mathrm{H} / \mathrm{L})$, width $(\mathrm{mm})$, individual average weight (IAW) (g), and survival (\%) at a) the intermediate culture and b) after 10 months of final grow-out cultivation in different density treatments. Density treatments of 50,100,200, and 400 represent the number of oysters $/ 0.10 \mathrm{~m}^{2}$ culture and density treatments of $30,60,120$, and 180 represent the number of oysters $/ 0.13 \mathrm{~m}^{2}$, respectively, in figures a and $b$. Least square means with different letters in the column were significantly different $(P<0.05)$ by Tukey's test.

et al., 2013). Legat et al. (2017b) cultivated C. tulipa for 300 days in Santa Catarina (south of Brazil), in marine and estuarine sites, and two estuarine sites in Maranhão state (north of Brazil). Results of this study showed that the estuarine site of Santa Catarina presented the best growth performance (final height of $71.96 \pm 8.05 \mathrm{~mm})$, followed by the marine site $(55.31 \pm$ $6.05 \mathrm{~mm}$ ), while in Maranhão estuarine sites, oysters did not reach a minimum of $50 \mathrm{~mm}$ in height.

Such previous promising results reflect the wide optimum tolerance range of $C$. tulipa for either hypersaline or hyposaline waters for extended periods (10-45 g L ${ }^{-1}$, Funo et al., 2015; Horodesky et al., 2019), which makes $C$. tulipa a proper species to farm in most coastal areas of Brazil.

Our study aimed to verify proper density thorough all steps of cultivating $C$. tulipa since the arrival of seeds in nursery structures to adult commercialization
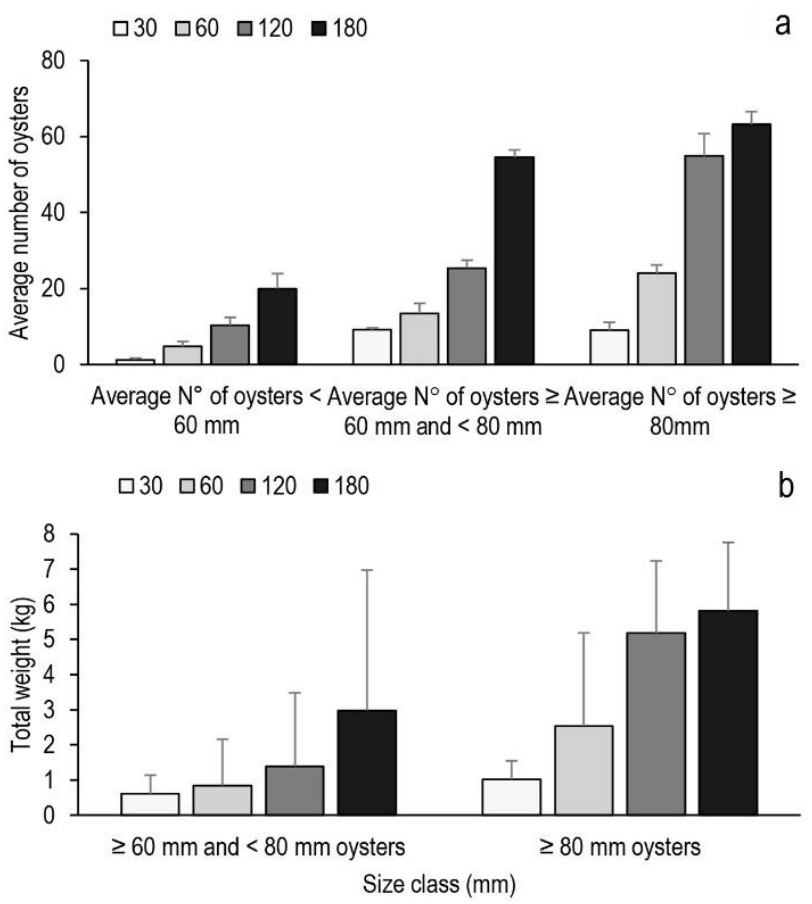

Figure 6. Mean \pm standard deviation of a) number of oysters and b) weight by size class after 10 months of final grow-out cultivation in different density treatments. Density treatments of 30,60,120, and 180 represent the number of oysters $/ 0.13 \mathrm{~m}^{2}$.

in grow-out farms located in marine areas. Analyses of the best stocking rate in oyster farming give information for organizing resources and establishing proper labor dynamics to minimize inputs and maximize the highest outputs (Shang, 1981; Asche et al., 2009). Such information contributes to spatial planning at the regional level to avoid environmental and production risks (Alleway et al., 2016).

Previous studies have attributed higher oyster growth rates to low-density treatments, which enhances the value of individual oysters per cultivated unit as cultivation becomes limited per area (Holliday et al., 1993; Mgaya \& Mercer, 1995; Alunno-Bruscia et al., 2001; Cardoso-Junior et al., 2012; Marshall \& Dunham, 2013; Azevedo et al., 2015; Roncarati et al., 2017). Additionally, overstocking situations usually drive cultivations toward a fragile state, mostly expressed in terms of increased time to marketable size and irregular growth (Beland, 1987), increased mortality, and, sometimes, individuals exhibiting morphological deformities or clumps (Galtsoff, 1964).

For nursery cultivation of oysters, however, growth in the height of seeds and $\mathrm{H} / \mathrm{L}$ ratio was significantly higher at more dense treatment, even though any density treatment evaluated could satisfy the cultivation of $C$. tulipa. Independent of density treatment, seed 
shape varied from round to oval, and $100 \%$ of individuals, at the $72^{\text {nd }}$ day of cultivation, surpassed $10 \times 10 \mathrm{~mm}$ size, a referential seed index utilized to evaluate the performance of nursery farm cultivation through seed sifting in Santa Catarina state (Ferreira et al., 2011). A similar pattern was also found for Sambaqui at the $63^{\text {rd }}$ day of cultivation, in which $95.3 \%$ of $C$. tulipa seeds surpassed $10 \mathrm{~mm}$ in height and length (Tureck et al., 2014).

The stocking density effect in nursery phase cultivation of $C$. tulipa was either null or insignificant for densities tested, as even the differences among them did not implicate less oyster yield or quality of seeds. Although such pattern of results is uncommon, other studies demonstrated the lack of negative density effect in C. gigas cultivated in floating boxes in the same region, in which different density treatments of 50 or $200 \mathrm{~mL} / 0.13 \mathrm{~m}^{2}$ seeds gave a yield similar to seeds retained at $\geq 3.0 \mathrm{~mm}$ mesh nets (Ferreira \& Ferreira, 2014). Besides, Galvão et al. (2009) showed that seed growth in nursery cultivation of Crassostrea sp. at either 150 or $450 \mathrm{ind} / 0.13 \mathrm{~m}^{2}$ (lantern floor) in the Cananéia Estuary $\left(25^{\circ} \mathrm{S}, 48^{\circ} \mathrm{W}\right)$ performed essentially the same. Therefore, the range of densities in our study and the study mentioned above were not wide enough to evince a more significant effect.

Higher density treatments could reduce the velocity of water current inside the cultivation system, thus enabling a more efficient filtering process, since current velocity is inversely related to feeding rate and growth (Cole et al., 1992; Honkoop \& Bayne, 2002), although a continuous water flow is essential in maintaining the availability of food in culture systems (Wilson-Ormond et al., 1997). Food availability in the study site was enough to maintain the densest treatment's growth rate, and food depletion, if it occurred, did not exhibit concerning aspects of oyster growth, shape, or survival. Additionally, a high density of oysters may increase water flux activity in the experimental units (EU) caused by bivalves' feeding pump currents (Nikora $e t$ al., 2002; Bayne, 2017). Additionally, oysters can physiologically compensate for a low quality and small quantity of food, expressed in increased clearance rate by functional changes in particle capture efficiency (Ward \& Shumway, 2004) and reduced pseudofaeces production (Bayne, 1993).

The balance between the amount of PIM and POM in seston determines whether bivalves efficiently establish a positive energy balance (Wallace \& Reinsnes, 1985; Hawkins et al., 2002). At large PIM portions, the quality of seston decreases as POM becomes either unavailable for absorption or does not fairly compensate energy used for selective filtering (Velasco \& Navarro, 2003; Bayne, 2017). Tureck et al.
(2014) showed a better yield of C. tulipa seeds in marine sites compared to estuarine sites, even though estuarine sites had more available POM (10.53 \pm 1.68 mg L ${ }^{-1}$ vs. $3.59 \pm 0.14 \mathrm{mg} \mathrm{L}^{-1}$ ) and lower PIM/POM ratio $(101.47 \pm 1.54 / 10.53 \pm 1.68 v s .55 .87 \pm 6.59 / 3.59$ \pm 0.14 ) than marine sites at similar temperature conditions, implying that salinity may influence the filtration rate. Local marine farming conditions at the study site are characterized by more available POM $\left(6.43 \pm 2.66\right.$ to $\left.17.41 \pm 5.33 \mathrm{mg} \mathrm{L}^{-1}\right)$ with variable PIM values $\left(19.55 \pm 4.13\right.$ to $\left.67.35 \pm 5.33 \mathrm{mg} \mathrm{L}^{-1}\right)$. With similar POM values, our initial yield of seeds at the $72^{\text {nd }}$ day of plant-out performed like that of Tureck et al. (2014), culturing marine species after 63 days and reporting the vast majority of seeds with a height greater than $10 \mathrm{~mm}$. This result suggests that seston utilization and related growth are less related to seasonal food and temperature fluctuations and more related to a wide range of physiologically regulated feeding and digestion (Riisgård, 2001; Ward \& Shumway, 2004).

The filtration rate of $C$. tulipa maintains a constant maximum activity at salinity variation of 35 to 18.3 with lower salinity values implicating less food uptake (Sutton et al., 2012). During farm cultivation, salinity ranged from $26 \pm 1.41$ to $35.80 \pm 0.45$, which indicates a good site for maximum filtration rate for species production.

Cultivation at the juvenile phase displayed a different growth pattern from those at nursery and final phases. Although significant differences were verified at some density treatments, the width of oysters maintained nearly the same values of seeds retained in $16 \mathrm{~mm}$ mesh at 114 days of cultivation. Rapid growth occurred especially in height and length and may be characteristic at this phase. In just 48 days of cultivation, most $C$. tulipa individuals reached $50 \mathrm{~mm}$ in all densities, values comparable to $C$. gigas cultivation at this phase, the cultivation period of which lasted from 60 to 450 days (Mizuta et al., 2012).

The final phase is defined as the period of final growth with adults' fattening process for commercialization. Usually, at the end of this cultivation phase, oysters must acquire conditions for their commercialization, during which the weight of meat comes into play (Lawrence \& Scott, 1982) since deshelling is a typical food process. However, in Brazil, shelled oysters are sold by the dozen, and quality is determined by oyster height and length, even if this means buying an oyster with a large shell and little flesh (Lopes et al., 2013). Oyster yield, as evaluated in the present work, reflects Brazilian market conditions.

Low survival of oysters at the final stage of cultivation is quite expected, but not for lower density 
treatments ( 30 and $60 \mathrm{ind} / 0.13 \mathrm{~m}^{2}$ ) compared to higher densities since the competition's effect is decreased (Holliday et al., 1993). Mainly, Sabry \& Magalhães (2005) found a similar survival rate percentage in $C$. rhizophorae oysters cultivated at $40 \mathrm{ind} / 0.13 \mathrm{~m}^{2}$, even though correctly managing individuals. Some studies indicate that biofouling encrustation in oysters is intensified at low densities (Adams et al., 1994; Dunham \& Marshall, 2012), as verified in C. tulipa cultivated in a Cananéia estuary (Pereira et al., 2001) and for the same $C$. tulipa specimens presented in this study (Lehner et al., 2019). Under these conditions, the total surface area exposed to biofouling colonization is higher, mostly when individuals are distributed in different sizes, thus creating more irregular colonization (Gutiérrez et al., 2003). Biofouling has various harmful effects, including competition for food and space, physical disruption to opening and closing of valves, and stress, precursors for increased mortality (Adams et al., 2011; Fitridge et al., 2012).

Evaluating the total amount of oysters of marketable quality per time spent in cultivation provides a real glimpse into the most profitable density treatments. Oysters' marketability is first based on the weight of individuals since it directly reflects their meat weight (Quayle \& Newkirk, 1989). The size of oysters measures another basis of marketability. However, the size considered ideal for commercializing mangrove oysters varies. Nascimento et al. (1980) indicate that the ideal commercial size of $C$. rhizophorae is approximately $70 \mathrm{~mm}$ in height. Pereira et al. (2003) considered a commercially minimum size of $50 \mathrm{~mm}$ in height for $C$. tulipa cultivated for one year in a natural environment. Here, we consider at least two marketable types of oysters based on size: oysters with a height between $60-80 \mathrm{~mm}$ and oysters with height $>80 \mathrm{~mm}$ with correspondingly higher meat and market appeal.

Legat et al. (2017b) observed that 95.6 and $24.1 \%$ of $C$. tulipa oyster's growth above $60 \mathrm{~mm}$ in height at eight months of cultivation, in São Francisco do Sul estuary and Sambaqui farm (southern region), respectively, although the average individual weight of each oyster did not exceed $70 \mathrm{~g}$. As for our results, all treatments showed a mean height of oysters above 70 $\mathrm{mm}$ and individual average weight of oysters with values exceeding $80 \mathrm{~g}$ at 10 months of cultivation. These experiments indicate that it is possible to obtain C. tulipa oysters in commercial size in a relatively short period of cultivation from marine farms.

In Brazil, apart from the present study, growth evaluation of native mangrove oysters has already been performed, e.g., Pereira et al. (2001) and, more recently, Lopes et al. (2013) and Legat et al. (2017b). Growth of mangrove oysters here and in these studies was lower than the growth of $C$. gigas in Santa Catarina as the Pacific oyster takes from 8 to 13 months of cultivation to grow from seeds to a commercial oyster size between 70 and $120 \mathrm{~mm}$ in height (Mizuta et al., 2012).

It should be noted that $C$. gigas is adapted to low water temperature, limiting and restricting its production, most notably in the summer and in areas where tropical conditions prevail, and the average temperature of the water is high, making the cultivation of $C$. gigas impractical (Poli, 2004; Gomes et al., 2014). In this sense, the production of $C$. tulipa appears to be an alternative species, as it has adapted to warmer regions and distributed in both tropical and subtropical climates. In both quantity and quality of meat, it is important to note that $C$. tulipa is very good, surpassing C. gigas, mainly in the meat quality, which can satisfactorily meet commercial demand.

The data obtained in the present research demonstrate remarkable growth and survival of $C$. tulipa and its potential for bringing subsidies to cultivate native oysters of great importance for economic development.

\section{ACKNOWLEDGMENTS}

We thank Fazenda Marinha Atlântico Sul that provided field support to carry out the experiments. This work was carried out with the support of Conselho Nacional de Desenvolvimento Científico e Tecnológico - Brasil $(\mathrm{CNPq})$ that provided a scholarship for the last author and Coordenação de Aperfeiçoamento de Pessoal de Nível Superior - Brasil (CAPES) that provided a scholarship for the first author. This study's success would not have been possible without the contribution of the staff members of the Laboratory of Marine Mollusks.

\section{REFERENCES}

Adams, C.M., Shumway, S.E., Whitlatch, R.B. \& Getchis, T. 2011. Biofouling in marine molluscan shellfish aquaculture: a survey assessing the business and economic implications of mitigation. Journal World Aquaculture Society, 42: 242-252.

Adams, M.P., Walker, R.L. \& Heffernan, P.B. 1994. The effects of stocking density, bag mesh size, and bottom sediment on the growth and survival of the eastern oyster, Crassostrea virginica, with emphasis on controlling oyster spat fouling. Journal Applied Aquaculture, 4: 25-44. doi: 10.1300/J028v04n04_03

Adite, A., Sonon, S.P. \& Gbedjissi, G.L. 2013. Feeding ecology of the mangrove oyster, Crassostrea gasar (Dautzenberg, 1891) in traditional farming at the 
coastal zone of Benin, West Africa. Natural Science, 5: 1238-1248. doi: 10.4236/ns.2013.512151

Afinowi, M.A. 1984. The mangrove oyster, Crassostrea gasar cultivation, and potential in the Niger Delta (Nigeria). Nigerian Institute for Oceanography \& Marine Research Lagos, 14: 1-13.

Ajana, A.M. 1980. Fishery of the mangrove oyster, Crassostrea gasar, Adanson (1757), in the Lagos area, Nigeria. Aquaculture, 21: 129-137.

Alleway, H.K., Thurstan, R.H., Lauer, P.R. \& Connell, S.D. 2016. Incorporating historical data into aquaculture planning. ICES Journal of Marine Science, 73: 1427-1436. doi: 10.1093/icesjms/fsv191

Alunno-Bruscia, M., Vercelli, C., Chabirand, J.M., Oheix, J. \& Buestel, D. 2001. Influence de la densité d'élevage sur la croissance et la qualité de l'huître creuse Crassostrea gigas dans l'étang de Thau. Rapport Interne IFREMER DRV/RA/LCM, 2001-06, 72 pp.

Angell, C. 1986. The biology and culture of tropical oysters. International Center for Living Aquatic Resources Management, Manila, Philippines. ICLARM Studies Reviews, 13: 1-42.

Ansa, E.J. \& Bashir, R.M. 2007. Fishery and culture potentials of the mangrove oyster (Crassostrea gasar) in Nigeria. Research Journal Biological Sciences, 2: 392-394.

Antunes, S.A. \& Itô, Y. 1968. Chemical composition of oysters from São Paulo \& Paraná, Brasil. Boletim do Instituto Paulista de Oceanografia, 17: 71-88.

Asche, F., Roll, K.H. \& Tveteras, R. 2009. Economic inefficiency and environmental impact: an application to aquaculture production. Journal of Environmental Economics and Management, 58: 93-105. doi: 10.1016/j.jeem.2008.10.003

Azevedo, R.V., Tonini, W.C.T., Dos Santos, M.J.M. \& Braga, L.G.T. 2015. Biofiltration, growth, and body composition of oyster Crassostrea rhizophorae in effluents from shrimp Litopenaeus vannamei. Revista Ciência Agronômica, 46(1): 193-203.

Bayne, B.L. 1993. Feeding physiology of bivalves: timedependence and compensation for changes in food availability. In: Dame, R.F. (Ed.). Bivalve filter feeders in estuarine and coastal ecosystem processes. Springer-Verlag, Berlin, pp. 1-24.

Bayne, B.L. 2017. Biology of oysters. Academic Press, London.

Beland, P. 1987. Summary of management of shellfish culture ecosystems. Séminaire International sur La recherche en soutien du développement et de l'aménagement de la Conchyliculture s'est tenu à La Rochelle (France) du 4 au 9 mars 1985. IFREMER, Issy-les-Moulineaux.

Cardoso Junior, L.D.O., Lavander, H.D., Da Silva Neto, S.R., De Souza, A.B., Da Silva, L.O.B. \& Gálvez,
A.O. 2012. Oyster Crassostrea rhizophorae growth farmed at different stocking densities in north coast of Pernambuco. Pesquisa Agropecuária Pernambucana, 17: 10-14. doi: 10.4322/pap.2012.003

Carranza, A., Defeo, O. \& Beck, M. 2009. Diversity, conservation status and threats to native oysters (Ostreidae) around the Atlantic and Caribbean coasts of South America. Aquatic Conservation: Marine Freshwater Ecosystems, 19: 344-353. doi: 10.1002/ aqc.993

Carpenter, K.E. \& De Angelis, N. 2016. The living marine resources of the Eastern Central Atlantic. Volume 2. Bivalves, gastropods, hagfishes, sharks, batoid fishes, and chimaeras. FAO species identification guide for fishery purposes. FAO, Rome, pp. 665-1509.

Cayré, P. 1981. Stocks de mollusques bivalves. In: Fontana, A. (Ed.). Milieu marin et ressources halieutiques de la République Populaire du Congo. ORSTOM, Paris, pp. 313-322.

Cham, M.A. 1992. Culture of the West African mangrove oyster (Crassostrea tulipa) in the Gambia. Aquaculture systems research in Africa: Proceedings of Workshop held in Bouake, Côte d'Ivoire, 14-17 Nov. 1988. IDRC, Ottawa.

Christo, S.W. \& Absher, T.M. 2006. Reproductive period of Crassostrea rhizophorae (Guilding, 1828) and Crassostrea brasiliana (Lamark, 1819) (Bivalvia: Ostreidae) in Guaratuba Bay, Paraná, Brazil. Journal of Coastal Research, 2: 1215-1218.

Christo, S.W., Ferreira Jr., A.L., Cruz-Kaled, A.C. \& Absher, T.M. 2016. Recruitment of oysters of Crassostrea genus (Bivalvia, Ostreidae) in Guaratuba Bay, PR, Brazil. Pan-American Journal of Aquatic Science, 11(4): 301-308.

Cole, B.E., Thompson, J.K. \& Cloern, J.E. 1992. Measurement of filtration rates by infaunal bivalves in a recirculating flume. Marine Biology, 113: 219-225. doi: 10.1007/BF00347274

Crow, B. \& Carney, J. 2013. Commercializing nature: mangrove conservation and female oyster collectors in the Gambia. Antipode, 45(2): 275-293. doi: 10.1111/ j.1467-8330.2012.01015.x

Dautzenberg, P. 1891. Voyage de la Goélette Melita aux Canaries et au Sénégal, 1889-1890. Mollusques testacés. Mémoires de la Société Zoologique de France, 4: 16-65.

Diadhiou, H.D. \& Ndour, I. 2017. Artificial capture of mangrove oyster spat Crassostrea gasar (Mollusca, Bivalvia) in Casamance estuary (Senegal). Aquaculture, Aquarium, Conservation and Legislation International Journal of the Bioflux Society, 10(1): 4855 . 
Dunham, A. \& Marshall, R.D. 2012. Using stocking density modifications and novel growth medium to control shell deformities and biofouling in suspended culture of bivalves. Aquaculture, 324-325: 234-241. doi: 10.1016/j.aquaculture.2011.10.047

Empresa de Pesquisa Agropecuária e Extensão Rural de Santa Catarina (EPAGRI). 2018. Síntese anual da agricultura de Santa Catarina 2017-2018. Epagri/ Cepa, Florianópolis. [http://webdoc.epagri.sc.gov.br/ sintese.pdf]. Reviewed: September 10, 2019.

Ferreira, F.M. \& Ferreira, J.F. 2014. Comparative efficiency and yield in different systems and densities at the nursery culture phase of the oyster Crassostrea gigas in Southern Brazil. Boletim de Indústria Animal, 71(2): 114-121. doi: 10.17523/bia.v71n2p114

Ferreira, J.F., Silva, F.C., Gomes, C.H.A. \& Ferreira, F.M. 2011. Produção programada e rastreabilidade de larvas e sementes de moluscos. Revista Brasileira de Reprodução Animal, 35: 192-207.

Fitridge, I., Guenther, J. \& de Nys, R. 2012. The impact and control of biofouling in marine aquaculture: a review. Biofouling, 28(7): 649-669. doi: 10.1080/08927014.2012.700478

Funo, I.C.S.A., Antonio, Í.G., Marinho, Y.F. \& Gálvez, A.O. 2015. Influência da salinidade sobre a sobrevivência e crescimento de Crassostrea gasar. Boletim do Instituto de Pesca, 41(4): 837-847.

Funo, I.C.S.A., Antonio, Í.G., Marinho, Y.F., Monteles, J.S., Lopes, R.G.P.S. \& Gálvez, A.O. 2019. Recruitment of oyster in artificial collectors on the Amazon macrotidal mangrove coast. Ciencia Rural, 49(3): 1-12.

Galtsoff, P.S. 1964. The American oyster Crassostrea virginica (Gmelin). Fish Bulletin US Department of the Interior Fish and Wildlife Service, Washington.

Galvão, M.S.N., Pereira, O.M., Machado, I.C., Pimentel, C.M.M. \& Henriques, M.B. 2009. Performance of juvenile culture of the mangrove oyster Crassostrea sp. in suspended lanterns in subtidal zone of the Cananéia estuary and Itaguá Bay, Ubatuba (São Paulo State, Brazil). Boletim do Instituto de Pesca, 35: 401411.

Gardunho, D.C.L., Gomes, C.P., Tagliaro, C.H. \& Beasley, C.R. 2012. Settlement of an unidentified oyster (Crassostrea) and other epibenthos on plastic substrates at a northern Brazilian mangrove island. Brazilian Journal of Aquatic Science Technology, 16(1): 41-51.

Gomes, C.H.A.M., Silva, F.C., Lopes, G.R. \& De Melo, C.M.R. 2014. The reproductive cycle of the oyster Crassostrea gasar. Brazilian Journal of Biology, 74(4): 967-976. doi: 10.1590/1519-6984.04912
Gruvel, A. 1913. Les principaux mollusques comestibles ou industriels. Annales de l'Institut Océanographique, 5: $132-146$.

Guilding, L. 1828. Observations on the zoology of the Caribbean Islands. Zoology Journal, 3: 542.

Gutiérrez, J.L., Jones, C.G., Strayer, D.L. \& Iribarne, O.O. 2003. Mollusks as ecosystem engineers: the role of shell production in aquatic habitats. Oikos, 101: 79-90. doi: 10.1034 /j.1600-0706.2003.12322.x

Hawkins, A.J.S., Duarte, P., Fang, J.G., Pascoe, P.L., Zhang, J.H., Zhang, X.L. \& Zhu, M.Y. 2002. A functional model of responsive suspension-feeding and growth in bivalve shellfish, configured and validated for the scallop Chlamys farreri during culture in China. Journal of Experimental Marine Biology and Ecology, 281: 13-40.

Holliday, J.E., Allan, G.L. \& Nell, J.A. 1993. Effects of stocking density on juvenile Sydney rock oysters, Saccostrea commercialis (Iredale \& Roughley), in cylinders. Aquaculture, 109: 13-26. doi: 10.1016/0044-8486(93)90482-E

Honkoop, P.J.C. \& Bayne, B.L. 2002. Stocking density and growth of the Pacific oyster (Crassostrea gigas) and the Sydney rock oyster (Saccostrea glomerata) in Port Stephens, Australia. Aquaculture, 213: 171-186. doi: 10.1016/S0044-8486(02)00030-3

Horodesky, A., Castilho-Westphal, G.G., Cozer, N., Rossi, V.G. \& Ostrensky, A. 2019. Efeitos da salinidade na sobrevivência e histologia de ostras Crassostrea gasar. Bioscience Journal, 35(2): 586597. doi: 10.14393/BJ-v35n2a2019-42099

Huber, M. 2015. Compendium of Bivalves 2. ConchBooks, Harxheim.

Instituto Brasileiro de Geografia e Estatistica (IBGE). 2019 Produção da pecuária municipal. Volume 43. IBGE, Rio de Janeiro.

Kamara, A.B. 1982. Preliminary studies to culture mangrove oysters, Crassostrea tulipa, in Sierra Leone. Aquaculture, 27(3): 285-294. doi: 10.1016/0044-8486 (82)90063-1

Lamarck, J.B.P.M. 1819. Histoire naturelle dês animaux sans vertebres. J.B. Baillière, Paris. doi: 10.5962/bhl. title. 12712

Lapègue, S., Boutet, I., Leitão, A., Heuertebise, S., Garcia, P., Thiriot-Quiévreux, C. \& Boudry, P. 2002. TransAtlantic distribution of mangrove oyster species revealed by $16 \mathrm{~S}$ mtDNA and karyological analyses. Biological Bulletin, 202: 232-242. doi: 10.2307/ 1543473

Lawrence, D.R. \& Scott, G.I. 1982. The determination and use of condition index of oysters. Estuary, 5(1): 23-27. 
Lazoski, C.V., Gusmão, J., Boudry, P. \& Solé-Cava, A.M. 2011. Phylogeny and phylogeography of Atlantic oyster species: evolutionary history, limited genetic connectivity, and isolation by distance. Marine Ecology Progress Series, 426: 197-212. doi: 10.3354/meps 09035

Legat, J.F.A., Pereira, A.M.L., Legat, A.P. \& Fogaça, F.H.S. 2008. Programa de cultivo de moluscos bivalves da Embrapa Meio-Norte. Embrapa MeioNorte, Teresina.

Legat, J.F.A., Puchnick-Legat, A., De Gomes, C.H.A., Sühnel, S. \& De Melo, C.M.R. 2017a. Efects of salinity on fertilization and larviculture of the mangrove oyster, Crassostrea gasar in the laboratory. Aquaculture. 468: 545-548. doi: 10.1016/j.Aquaculture.2016.11.016

Legat, J.F.A., Puchnick-Legat, A., Dos Santos Fogaça, F.H., Tureck, C.R., Sühnel, S. \& De Melo, C.M.R. 2017b. Crescimento e sobrevivência da ostra de fundo, Crassostrea gasar, cultivada no nordeste e sul do Brasil. Boletim do Instituto de Pesca, 43: 172-184. doi: 10.20950/1678-2305.2017v43n2p172

Lehner, R., Brunetto, L.J., Vieira, G.C., Do Nascimento, V.S., Gomes, C.H.A.M., Graff, G.F.F., et al. 2019. Efeito da densidade de cultivo sobre a quantidade de incrustantes, crescimento e sobrevivência de ostras nativas Crassostrea gasar. IV Encontro de Malacologia do Paraná, Universidade Positivo, Curitiba.

Lopes, G.R., Gomes, C.H.A.M., Tureck, C.R. \& De Melo, C.M.R. 2013. Growth of Crassostrea gasar cultured in marine and estuary environments in Brazilian waters. Pesquisa Agropecuária Brasileira, 48: 975-982. doi: 10.1590/S0100-204X2013000800024

Maccacchero, G.B., Guzenski, J. \& Ferreira, J.F. 2005. Allometric growth on mangrove oyster Crassostrea rhizophorae (Guilding, 1828), cultured in Southern Brazil. Revista Ciência Agronômica, 36: 400-403.

Marshall, R.D. \& Dunham, A. 2013. Effects of culture media and stocking density on biofouling, shell shape, growth, and survival of the Pacific oyster (Crassostrea gigas) and the Manila clam (Venerupis philippinarum) in suspended culture. Aquaculture, 406-407: 68-78. doi: 10.1016/j.aquaculture.2013.05.003

Mendonça, J.T. \& Machado, I.C. 2010. Mangrove oyster (Crassostrea spp.) (Sacco, 1897) extractivism in Cananéia estuary (São Paulo, Brazil) from 1999 to 2006: capture and management evaluation. Brazil. Journal of Biology, 70(1): 65-73. doi: 10.1590/S151969842010000100010

Mgaya, Y.D. \& Mercer, J.P. 1995. The effects of size grading and stocking density on growth performance of juvenile abalone, Haliotis tuberculata Linnaeus.
Aquaculture, 136: 297-312. doi: 10.1016/0044-8486 (95)00066-6

Ministério da Pesca e Aquicultura (MPA). 2011. Boletim Estatístico da Pesca e Aquicultura - Brasil 2010. MPA, Brasília. [https://www.icmbio.gov.br/cepsul/images/ stories/biblioteca/download/estatistica/est_2010_na c_boletim.pdf]. Reviewed: September 6, 2019.

Mizuta, D.D., Silveira, N., Fischer, C.E. \& Lemos, D. 2012. Interannual variation in commercial oyster (Crassostrea gigas) farming in the sea (Florianópolis, Brazil, $27^{\circ} 44^{\prime} \mathrm{S} ; 48^{\circ} 33^{\prime} \mathrm{W}$ ) in relation to temperature, chlorophyll a and associated oceanographic conditions. Aquaculture, 366: 105-114. doi: 10.1016/j.aquaculture.2012.09.011

Nalesso, R.C., Paresque, K., Piumbini, P.P., Tonini, J.F.R., Almeida, L.G. \& Níckel, V.M. 2008. Oyster spat recruitment in Espírito Santo State, Brazil, using recycled materials. Brazilian Journal of Oceanography, 56(4): 281-288. doi: 10.1590/S1679-8759 2008000400003

Nascimento, I.A. 1990. Biological characteristics of mangrove oyster in Brazil as a basis for their cultivation. In: Newkirk, G.F. \& Field, B.A. (Eds.). Oyster culture in the Caribbean. Mollusc Culture Network, Canada, pp. 17-33.

Nascimento, I.A., Pereira, S.A. \& Souza, R.C.E. 1980. Determination of the optimum commercial size for the mangrove oyster (Crassostrea rhizophorae) in Todos os Santos Bay, Brazil. Aquaculture. 20: 1-8. doi: 10.1016/0044-8486(80)90056-3

Nicklès, M. 1950. Mollusques testacés marins de la côte occidentale d'Afrique. P. Lechevalier, Paris.

Nikora, V., Green, M.O., Thrush, S.F., Hume, T.M. \& Goring, D. 2002. Structure of the internal boundary layer over a patch of pinnid bivalves (Atrina zelandica) in an estuary. Journal of Marine Research, 60(1): 121150. doi: $10.1357 / 002224002762341276$

Oliveira, L.F.S., Ferreira, M.A.P., Juen, L., Nunes, Z.M.P., Pantoja, J.C.D., da Paixão, L.F., De Lima, M.N.B. \& Da Rocha, R.M. 2018. Influence of the proximity to the ocean and seasonality on the growth performance of farmed mangrove oysters (Crassostrea gasar) in tropical environments. Aquaculture, 495: 661-667. doi: 10.1016/j.aquaculture.2018.06.049

Paixão, L., Ferreira, M.A., Nunes, Z., Fonseca-Sizo, F. \& Rocha, R. 2013. Effects of salinity and rainfall on the reproductive biology of the mangrove oyster (Crassostrea gasar): implications for the collection of broodstock oysters. Aquaculture, 6(12): 380-383. doi: 10.1016/j.aquaculture.2012.11.019

Pereira, O.M. \& Soares, D.C. 1996. Analysis on cultivation of oyster Crassostrea brasiliana (Lamarck, 
1819) at Guarapari Station, in Cananéia-SP lacunarestuarine region. Boletim do Instituto de Pesca, 23: 135-142.

Pereira, O.M., Machado, I.C., Henriques, M.B. \& Yamanaka, N. 2001. Growth of the oyster Crassostrea brasiliana sewed on artificial beds under different densities in the estuarine lagoon of Cananéia, São Paulo, Brazil $\left(25^{\circ} \mathrm{S}, 48^{\circ} \mathrm{W}\right)$. Boletim do Instituto de Pesca, 27: 163-174.

Pereira, O.M., Henriques, M.B. \& Machado, I.C. 2003. Estimativa da curva de crescimento da ostra Crassostrea brasiliana em bosques de mangue e proposta para sua extração ordenada no estuário de Cananéia, SP, Brasil. Boletim do Instituto de Pesca, 29(1): 19-28.

Pie, M.R., Ribeiro, R.O., Boeger, W.A., Ostrensky, A., Falleiros, R.M. \& Ângelo, F. 2006. A simple PCRRFLP method for the discrimination of native and introduced oyster species (Crassostrea brasiliana, $C$. rhizophorae and $C$. gigas; Bivalvia: Ostreidae) cultured in Southern Brazil. Aquaculture Research, 37: 1598-1600. doi: 10.1111/j.1365-2109.2006.01591.x

Poli, C.R. 2004. Cultivo de ostras do Pacífico (Crassostrea gigas). In: Poli, C.R., Poli, A.T., Andreatta, E. \& Beltrame, E. (Eds.). Aquicultura: experiências brasileiras. Ed. Multitarefa, Florianópolis, pp. 251-266.

Quayle, D.B. \& Newkirk, G.F. 1989. Farming bivalve molluscs: methods for study and development. World Aquaculture Society, Baton Rouge.

Ramos, C.O., Ferreira, J.F. \& De Melo, C.M.R. 2013. Maturation of native oyster Crassostrea gasar at different diets in the laboratory. Boletim do Instituto de Pesca, 39(2): 107-120.

Ramos, C.O., Gomes, C.H.A.M., Magalhães, A.R.M., Santos, A.I.D. \& De Melo, C.M.R. 2014. Maturation of the mangrove oyster Crassostrea gasar at different temperatures in the laboratory. Journal Shellfish Research, 33(1): 187-194. doi: 10.2983/035.033.0118

Ranson, G. 1948. Ecologie et répartition géographique des ostréidés vivants. Revue de Science, 86: 469-473.

Reece, K.S., Cordes, J.F., Stubbs, J.B., Hudson K.L. \& Francis, E.A. 2008. Molecular phylogenies help resolve taxonomic confusion with Asian Crassostrea oyster species. Marine Biology, 153: 709-721.

Rios, E.C. 2009. Compendium of Brazilian sea shells. Evangraf, Rio Grande.

Riisgård, H.U. 2001. On measurement of filtration rates in bivalves - the stony road to reliable data: review and interpretation. Marine Ecology Progress Series, 211: 275-291.

Roncarati, A., Felici, A., Magi, G.E., Bilandžić, N. \& Melotti, P. 2017. Growth and survival of cupped oysters (Crassostrea gigas) during nursery and pregrowing stages in open sea facilities using different stocking densities. Aquaculture International, 25: 1777-1785. doi: 10.1007/s10499-017-0152-Z

Sabry, R.C. \& Magalhães, A.R.M. 2005. Parasitas em ostras de cultivo (Crassostrea rhizophorae e Crassostrea gigas) da Ponta do Sambaqui, Florianópolis, SC. Arquivo Brasileiro de Medicina Veterinária e Zootecnia, 57(2): 194-203. doi: 10.1590/S0102-093 52005000800010

Sandisson, E.E. 1966. The effect of salinity fluctuations on the life cycle of Gryphaea gasar in Lagos Harbour, Nigeria. Journal of Animal Ecology, 35: 379-389.

Statistical Analysis System (SAS). 2003. SAS: Statistical analysis system-getting started with the sas learning edition. SAS Institute, North Carolina.

Shang, Y.C. 1981. Aquaculture economics: basic concepts and methods of analysis. Westview Press, Colorado.

Silveira, R.C., Silva, F.C., Gomes, C.H.A.M., Ferreira, J.F. \& De Melo, C.M.R. 2011. Larval settlement and spat recovery rates of the oyster Crassostrea brasiliana (Lamarck, 1819) using different systems to induce metamorphosis. Brazilian Journal of Biology, 71: 557-562. doi: 10.1590/S1519-69842011000300 029

Strickland, J.D.H. \& Parsons, T.R. 1972. A practical handbook of seawater analysis. The Alger Press, Ottawa.

Sutton, A.E., Yankson, K. \& Wubah, D.A. 2012. The effect of salinity on particle filtration rates of the west African mangrove oyster. Journal of Young Investigators, 24(4): 55-59.

Taylor, J.J., Rose, R.A., Southgate, P.C. \& Taylor, C.E. 1997. Effects of stocking density on growth and survival of early juvenile silver-lip pearl oysters, Pinctada maxima (Jameson), held in suspended nursery culture. Aquaculture, 153: 41-49. doi: 10.1016/ S0044-8486(97) 00015-X

Thunberg, C.P. 1793. Tekning och Beskrifning på en stor Ostronsort ifrån Japan. Kongliga Vetenskaps Academiens Nya Handlingar, 14(4-6): 140-142.

Tureck, C.R., Vollrath, F., De Melo, C.R.M. \& Ferreira, J.F. 2014. Rendimento de sementes da ostra Crassostrea gasar produzidas em laboratório e cultivadas em Santa Catarina, Brasil. Boletim do Instituto de Pesca, 40(2): 281-290.

Tureck, C.R., De Melo, C.M.R., Gomes, C.H.A.M., Lazoski, C., Marenzi, A.W.C., et al. 2020. Use of artificial collectors to obtain oyster seeds in Babitonga Bay, Santa Catarina, Brazil. Boletim do Instituto de Pesca, 46(1): e541. doi: 10.20950/1678-2305.2020. 46.1.541

Velasco, L.A. \& Navarro, J.M. 2003. Energetic balance of infaunal (Mulinia edulis King, 1831) and epifaunal 
(Mytilus chilensis Hupé, 1854) bivalves in response to wide variations in concentration and quality of seston. Journal of Experimental Marine Biology and Ecology, 296(1): 79-92. doi: 10.1016/S0022-0981(03)00316-2

Wakamatsu, T. 1973. A ostra de Cananéia e seu cultivo. Superintendência do Desenvolvimento do Litoral Paulista/Instituto Oceanográfico USP, São Paulo.

Wallace, J.C. \& Reinsnes, T.G. 1985. The significance of various environmental parameters for growth of the iceland scallop, Chlamys islandica (Pectinidae), in hanging culture. Aquaculture, 44: 229-242.

Ward, J.E. \& Shumway, S.E. 2004. Separating the grain from the chaff: particle selection in suspension- and deposit-feeding bivalves. Journal of Experimental Marine Biology and Ecology, 300(1-2): 83-130. doi: 10.1016/j.jembe.2004.03.002

Received: 16 October 2019; Accepted: 2 September 2020
Westphal, G.G.C. \& Ostrensky, A. 2016. Use of side-scan sonar for estimations of Crassostrea brasiliana (Lamarck, 1819) stocks in subtidal banks on the south coast of Brazil. Brazilian Journal of Oceanography, 64(1): 49-56. doi: 10.1590/S1679-8759201610450 6401

Wilson-Ormond, E.A., Powell, E.N. \& Ray, S.M. 1997. Short-term and small-scale variation in food availability to natural oyster populations: food, flow and flux. Marine Ecology, 18(1): 1-34.

Yankson, K. 1999. A note of the nomenclature of the West African mangrove oyster. Ghana Science Association, Accra.

Zabi, G.S. \& Le Loeuff, P. 1992. Revue des connaissances sur la faune benthique des milieux marginelittoraux d'Afrique de l'Ouest. Première partie: biologie et écologie des espèces. Revue d'Hydrobiologie Tropicale, 25: 209-251. 